\title{
Expression of the ZFX Gene in Mouse Kidney During Postnatal Development
}

\author{
Xiangzu Wang, ${ }^{1,2}$ Jifeng Xi, ${ }^{1,2}$ Bin Jia, ${ }^{1, *}$ Yongsheng Zhang, ${ }^{1}$ and Chaocheng Li ${ }^{1}$ \\ ${ }^{1}$ College of Animal Science and Technology, Shihezi University, ShiHeZi, XinJiang \\ 832003, China \\ ${ }^{2}$ Xinjiang Agricultural Vocational Technical College, ChangJi, XinJiang 831100, \\ China
}

Xiangzu Wang and Jifeng Xi contributed equally to this article.

\begin{abstract}
A B S T R A C T
The relationship of cell proliferation and apoptosis is important in normal kidney development. The ZFX gene is important for regulation of growth, proliferation and differentiation in tissue cells while the Bcl2 and BAX genes regulate apoptosis. This experiment adopted the real-time fluorescence quantitative technique to test ZFX, Bcl-2, and BAX expression in mice kidney tissue on $1 \mathrm{~d}, 7 \mathrm{~d}, 14 \mathrm{~d}, 21 \mathrm{~d}, 42 \mathrm{~d}$, and $90 \mathrm{~d}$ after birth. The results showed that with the maturation of mouse kidney, the cell proliferation activity decreased, and the expression of ZFX, Bcl-2, and BAX were down regulated. The ZFX gene may participate in the developmental process of the kidney through the balance of cell proliferation and apoptosis regulation.
\end{abstract}

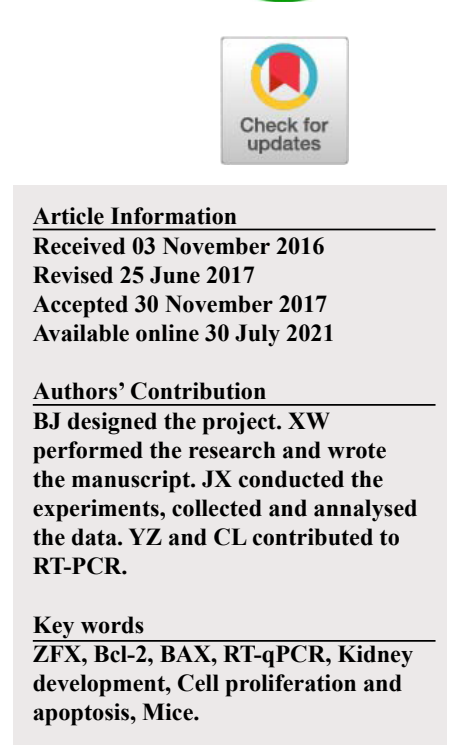

\section{INTRODUCTION}

Z inc finger protein $\mathrm{X}$-linked (ZFX) is a member of the zinc finger protein super family and contains $13 \mathrm{C} 2 \mathrm{H} 2$-type zinc finger structures. The ZFX gene is on the $\mathrm{x}$ chromosome in mammals, and its expression is highly conservative. The structure of ZFX contains an acidic transcriptional activation domain (AD), a nuclear localization sequence (NLS), and a DNA binding domain (DBD). Early research suggested the ZFX gene was associated with sex determination of mammals (Schneider-Gadicke et al., 1989). In recent years, research documented that ZFX plays an important role in selfrenewal and anti-apoptotic mechanisms of embryonic stem cells, adult hematopoietic stem cells, lymphoid cells and several other types of stem cells (GalanCaridad et al., 2007; Arenzana et al., 2009). Considering the characteristics of the tumor and stem cell, oncology studies found ZFX was abnormally expressed in laryngeal carcinoma's, glioma's, gastric cancer, prostate cancer, breast cancer and other common human malignancies, and it may also be involved in the regulation of tumor cell proliferation and anti-apoptotic processes (Jiang et al., 2012; Nikpour et al., 2012; Zhou et al., 2011). Since the zinc finger protein is a transcription factor which has a

\footnotetext{
* Corresponding author: jiabin@shzu.edu.cn 0030-9923/2021/0005-1867 \$ 9.00/0

Copyright 2021 Zoological Society of Pakistan
}

finger-like domain, it can combine with the promoter region thereby regulating gene expression, and also plays an important role in the growth, proliferation and differentiation of tissue cells (Chandrasekharan et al., 2009; Schnidar et al., 2009). There are two categories of apoptosis regulatory genes which contain apoptosis inhibition genes and apoptosis promotion genes. Bcl-2 is the most important anti-apoptotic gene while BAX is a major pro-apoptotic gene (Kallio et al., 2004; Yamamoto et al., 2004).

The development of the mammalian kidney includes stages of pronephros, mesonephros and metanephros, and the three stages are consecutive in the timing and location (Lipschutz, 1998; Davies, 2002). The appearance of mouse pronephros is at embryonic day 8 (E8), mesonephros is initiated at E9.5, and metanephros begins at E11 with the appearance of a small epithelial buds or diverticulum from the lower end of the mesonephric duct near its entry into the cloaca; the completion of the number of glomeruli in mice is on day 7 postpartum, with completion of kidney medulla on day 21 , and by day 42 the structure of kidney is the same as the adult (Nyengaard, 1993).

Real-time, reverse transcription quantitative PCR (RTqPCR) is a highly sensitive and reproducible technology for the analysis of gene expression patterns. In this study, by quantitative real-time technique ZFX, Bcl-2 and BAX expression at different stages of kidney development in mice after birth were evaluated, to determine the expression of ZFX during kidney development. 
Table I.- Conditions of PCR and oligonucleotide primer pairs.

\begin{tabular}{|c|c|c|c|c|}
\hline Target gene & GenBank No. & Sequence of primer (5'-3') & Annealing temp. & Products \\
\hline \multirow[t]{2}{*}{ ZFX } & NM_011768.2 & F: CAGATCCGTTTGTACTAAGTCGC & $61^{\circ} \mathrm{C}$ & 147 bp \\
\hline & & R: ACTGATACACTTTCCGGCCACT & & \\
\hline \multirow[t]{2}{*}{ Bcl-2 } & NM_011768.2 & F: GTCGCTACCGTCGTGACTTC & $61^{\circ} \mathrm{C}$ & $284 \mathrm{bp}$ \\
\hline & & R: CAGACATGCACCTACCCAGC & & \\
\hline \multirow[t]{2}{*}{ BAX } & NM_007527.3 & F: CGGCGAATTGGAGATGAACTG & $61^{\circ} \mathrm{C}$ & $161 \mathrm{bp}$ \\
\hline & & R: GCAAAGTAGAAGAGGGCAACC & & \\
\hline \multirow[t]{2}{*}{ GAPDH } & NM_008084.2 & F: ACCCAGAAGACTGTGGATGG & $61^{\circ} \mathrm{C}$ & $171 \mathrm{bp}$ \\
\hline & & R: CACATTGGGGGTAGGAACAC & & \\
\hline
\end{tabular}

\section{MATERIALS AND METHODS}

\section{Animals}

Clean adult mice were obtained from the Experimental Animal Center, Shihezi University. Mice were housed in clean, controlled environment, with food and water available ad libitum. Room conditions included maintenance of temperature at $24^{\circ} \mathrm{C}$, humidity at $50 \%$, with lighting from 8:00-20:00. After adaptation for 7 days, mice were paired and bred. The next morning females with vaginal plugs were separated for production of experimental litters. Kidneys of progeny aged 1, 7, 14, 21, 42 and 90 days were removed immediately after the animals were killed by cervical dislocation. The tissues stored in liquid nitrogen for reverse transcription-quantitative realtime polymerase chain reaction (RT-qPCR).

\section{Primary reagents}

Trizol was purchased from Invitrogen Life Technologies, Carlsbad, CA, USA, reverse transcription kits were purchased from Takara Co., Dalian, China, diethyl pyrocarbonat was purchased from Sigma (Santa Clara, CA, USA), agarose was purchased from GeneTech Co., Shanghai, China, DNA Marker was purchased from Tiangen Co., Beijing, China, SYBR ${ }^{\circledR}$ Premix Ex Taq ${ }^{\text {TM }}$ (TaKaRa), 96-well plates and cover films were purchased from Applied Biosystems Inc., CA, USA and SYBR Green SuperMix was acquired from Qiagen, Valencia, CA, USA.

\section{$R N A$ extraction and reverse transcription}

Total RNA was extracted from kidneys cryopreserved with liquid nitrogen using Trizol following the manufacturer's instructions. Reverse transcription of RNA was carried out using the gDNA Eraser PrimerScript RT reagent kit according to the manufacturer's instructions.

\section{Primer design}

According to the principles of primer design (Rodríguez et al., 2015; Livak et al., 2001), Primer Premier 5.0 software was applied to design the primer sequences of ZFX, BAX, Bcl-2, and GAPDH, The primer sequences was synthesized by BGI (Table I).

Conventional PCR assays

To detect primer specificity, and the quality of the template, PCR was conducted in advance. The amplification system was as follows: cDNA $1 \mu \mathrm{l}$, PCR reaction mixture (Mix) 10 $\mu$ l, upstream and downstream of each primer, $0.5 \mu \mathrm{l}, \mathrm{ddH}_{2} \mathrm{O} 8 \mu \mathrm{l}$. Reaction conditions were: $94^{\circ} \mathrm{C}$ denaturation for $5 \mathrm{~min} ; 94^{\circ} \mathrm{C}$ denaturation $30 \mathrm{~s}$, $61^{\circ} \mathrm{C}$ annealing $30 \mathrm{~s}, 72^{\circ} \mathrm{C}$ extension $50 \mathrm{~s}, 30$ cycles; $72^{\circ} \mathrm{C}$ extension $10 \mathrm{~min}$. Finally, $10 \mu \mathrm{l}$ of PCR products were run on $2.0 \%$ agarose gel, and then analyzed by a gel imager analysis system (need to specify the system).

\section{$R T-q P C R$}

Reverse transcription-quantitative real-time polymerase chain reaction (RT-qPCR) was conducted using a LightCycler 2.0 instrument (Roche, Basel, Switzerland), with SYBR Green SuperMix, following the manufacturer's instructions. Each sample was tested three times to insure accuracy. The amplification system was as follows: cDNA $2 \mu \mathrm{l}$, SYBR@ Premix Ex TaqTM $(2 \times)$ mixture (Mix) $10 \mu \mathrm{l}$, upstream and downstream of each primer, $0.4 \mu \mathrm{l}$, sterile distilled water to $20 \mu \mathrm{l}$. Reaction conditions were: initial denaturation step $\left(30 \mathrm{~s}\right.$ at $\left.95^{\circ} \mathrm{C}\right), 45$ cycles of $95^{\circ} \mathrm{C}$ for $10 \mathrm{~s}, 61^{\circ} \mathrm{C}$ for $30 \mathrm{~s}$, and $72^{\circ} \mathrm{C}$ for $30 \mathrm{~s}$.

\section{Statistical analysis}

Numerical analysis was done using the $2^{-\Delta \Delta} \mathrm{CT}$ method using the Gapdh gene as an internal standard. Data were analyzed using SPSS 17.0 (city, state, USA). Tests of hypotheses were done using t-tests with $\mathrm{P}<0.05$ considered statistically significant.

\section{RESULTS}

Amplified products of ZFX, Bcl2, BAX and GAPDH

The cDNA were amplified with $\mathrm{ZFX}, \mathrm{Bcl}_{2}, \mathrm{BAX}$ and GAPDH primers (Table I) to obtain $147 \mathrm{bp}, 284 \mathrm{bp}, 161 \mathrm{bp}$ 
and 171 bp products (Figs. 1, 2), respectively. According to the results of the gel imaging system, primers had excellent specificity and the qualities of the templates were reliable.

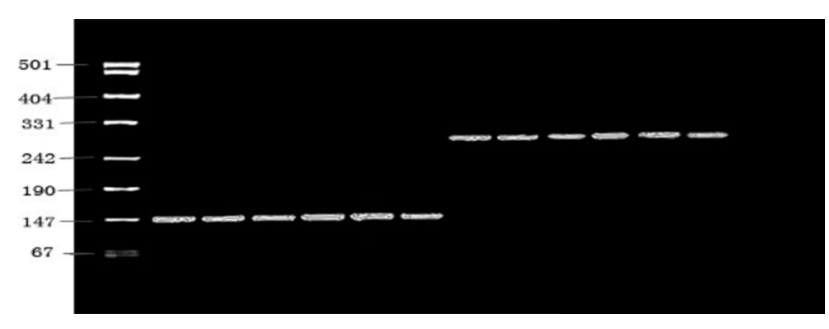

Fig. 1. PCR amplification of ZFX and Bcl-2.

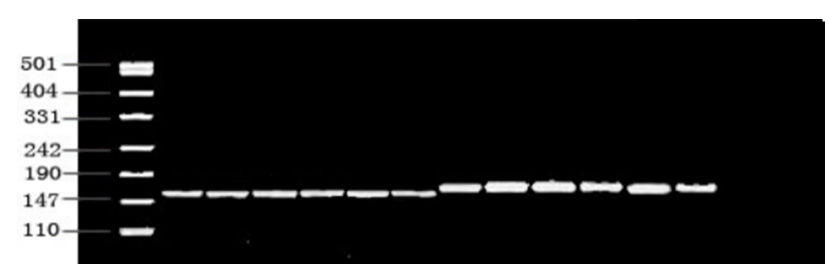

Fig. 2. PCR amplification of BAX and GAPDH.

\section{Expression analysis of $Z F X$}

RT-qPCR was performed to determine if ZFX mRNA displayed an age-dependent expression pattern and results indicated an age-dependent change of ZFX mRNA expression in the postnatal mouse kidney. ZFX mRNA expression was greatest on the day 1 , and then dropped gradually from day 1 through day 21 with the least expression on day $21(\mathrm{P}<0.01)$. Day 42 had similar expression to day $21(\mathrm{P}>0.05)$ while day 90 was slightly greater $(\mathrm{P}<0.05)$ (Fig. 3A).

\section{Expression analysis of $\mathrm{Bcl}-2$}

The mRNA level of Bcl-2 also displayed an agedependent expression pattern. On day 1, the expression of Bcl-2 was greatest, but lesser on days 7-90 ( $\mathrm{P}<0.01)$. The least expression occurred day 21 compared to days $1-14(\mathrm{P}$ $<0.01)$ with days 42 and 90 similar to day $21(\mathrm{P}>0.05)$ (Fig. 3B).

\section{Expression analysis of $B A X$}

The mRNA level of BAX in different periods of postnatal mouse kidney showed a trend similar to Bcl-2. Expression of BAX was greatest on day 1, and then declined on day $7(\mathrm{P}<0.01)$ and day $14(\mathrm{P}<0.01)$ until reached the least expression on day $21(\mathrm{P}<0.01)$, Expression of $\mathrm{BAX}$ increased slightly on day $42(\mathrm{P}<0.05)$ but expression on day 90 was similar to day $21(\mathrm{P}>0.05)$ (Fig. $3 \mathrm{C})$.

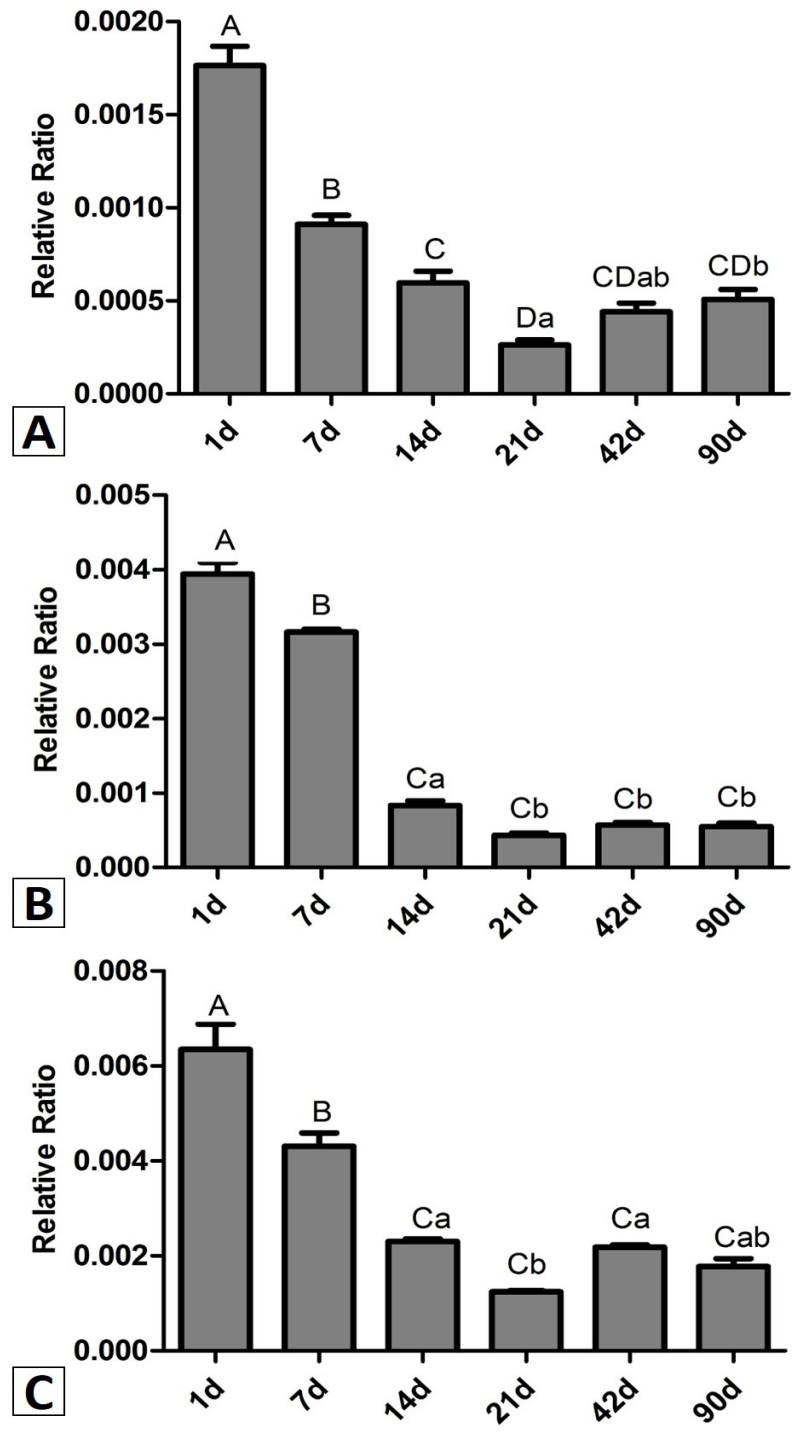

Fig. 3. mRNA expression of ZFX (A), Bcl-2 (B) and BAX (C) detected by RT-qPCR. Columns with the same letters indicate no difference between the two groups $(\mathrm{P}>0.05)$. Columns with differing capital letters differ $(\mathrm{P}<0.01)$ and columns with differing lowercase letters differ $(\mathrm{P}<0.05)$.

\section{DISCUSSION}

Zinc finger protein plays an important role in the proliferation and differentiation of cells. The ZFX gene products are necessary for maintaining embryonic stem cells and adult stem cell self-renewal, and are a common molecular basis of embryonic stem cells development and adult stem cell regeneration (Cellot et al., 2007; Ouyang et al., 2009). Inactivation of the ZFX gene has been shown to cause increased mortality of neonatal mice and decreased reproductive capacity of surviving maternal mice (Luoh et 
al., 1997). These studies also demonstrated that ZFX was closely related to cell proliferation.

Cell proliferation and apoptosis in mouse kidney development is regulated by a number of genes (Terzi et $a l ., 2000)$ and normal growth and development involves a balance relationship of cell proliferation and apoptosis. On day 1 of kidney development, the cell proliferation index of medullary collecting duct and renal tubular tissue was greater than the apoptosis index, with proliferation dominant. On day 7, cell apoptosis was dominant and cells begin to differentiate into mature cells. On day 14, the cell number and size of renal tubular and collecting duct tissue was not predominant with proliferation and apoptosis both at lesser levels. On day 21, the renal cortex and medulla were thickened with the development of the inner medulla, and cell proliferation decreased. At 42 days after birth, the adult kidney structure was largely formed and cell proliferation and apoptosis were in a relatively balanced state (Li et al., 2006).

The Bcl-2 and BAX genes belong to the Bcl-2 family. The Bcl-2 gene is an anti-apoptotic gene and BAX is a proapoptotic gene, and are important genes in regulating cells apoptosis. The mechanism of Bcl-2 is through production of antioxidant, inhibiting the release of pro-apoptotic protein and inhibiting the cytotoxicity of BAX to achieve an antiapoptotic effect. The BAX gene can form homodimers, damaging mitochondrial membranes, and the appearance of apoptosome in the cytoplasm, activating Caspase cascade activation, triggers the fragmentation of DNA and damage to a variety of cellular proteins components, which accelerates cell death (Saikumar et al., 1998; Yang et al., 1997). During postnatal kidney development Bcl-2 and BAX are both necessary for regulating cells apoptosis, and Bcl-2 deficient mice demonstrate polycystic kidneys (Veis et al., 1993).

SYBR Green reverse transcriptase quantitative PCR (RT-qPCR) is the most widely method used to investigate gene expression in ruminants. The increase in the fluorescent signal is directly proportional to the number of PCR product molecules generated. It possible to simultaneously characterize different genes, using small quantities of sample with high specificity, sensitivity and accuracy (Giulietti et al., 2001; Bustin, 2000).

In our study ZFX, Bcl-2, and BAX mRNA was confirmed to display an age-dependent expression pattern by RT-qPCR, mRNA expression figures were done to determine: (i) the relationship between the mRNA expression of ZFX, Bcl-2 and BAX; and (ii) whether ZFX mRNA age-dependent expression tendency was consistent with those of Bcl-2 and BAX. Results showed that mRNA expression of the ZFX, Bcl-2, and BAX genes was detected in all stages of postnatal kidney development and displayed similar age-dependent changes. On day 1 of early development of medulla ZFX was strongly expressed, and with the maturation in medulla development, ZFX expression decreased gradually until 21 days when the medulla was fully developed and the expression of ZFX reached the minimum. While the expression trend of Bcl2 and Bax during the development of postnatal kidney showed the cell proliferation and apoptosis were have the same patterns which were consistent with Zang et al. (2007). These results suggested that during the development of postnatal kidney, ZFX might ensure cell proliferation and viability, to promote cell further maturation. However, after day 42 when the kidney is mature, ZFX expression was increased so that renal cell proliferation and apoptosis were in relative equilibrium.

It was reported that ZFX was significantly upregulated in renal cell carcinoma (RCC) tissues (Li et al., 2015), and knockdown of ZFX suppresses renal carcinoma cell growth and induces apoptosis (Fang et al., 2014). In addition congenital anomalies of the kidney and urinary tract (CAKUT)/ cystic kidney disease is the first primary cause of the end-stage renal disease (ESRD) in China's children (Tang et al., 2014). According the expression pattern of ZFX in the postnatal kidney in our research, ZFX may be involved in the process of developing renal cell proliferation and balanced regulation of apoptosis.

\section{CONCLUSION}

In this study, ZFX gene expression in the different maturation state of mouse kidney was tested using the real-time fluorescence quantitative technique, meanwhile Bcl-2, and BAX expression was tested. Through the comparison, it showed the ZFX gene may participate in the developmental process of the kidney through the balance of cell proliferation and apoptosis regulation. However, the role of ZFX in the balance of cell proliferation and apoptosis in kidney development needs further protein test to confirm or refute this hypothesis, and it maybe provide some information to research on the end-stage renal disease.

\section{ACKNOWLEDGEMENTS}

This study was supported by a grant from the animal and plant breeding special project of Shihezi University, China (GXJS2013-YZ07) and a grant from the scientific research foundation of Xinjiang Agricultural Vocational Technical College, China (XJNZYKJ2014004).

Statement of conflict of interest

Authors have declared no conflict of interest. 


\section{REFERENCES}

Arenzana, T.L., Smith-Raska, M.R. and Reizis, B., 2009. Transcription factor ZFX controls BCR-induced proliferation and survival of $\mathrm{B}$ lymphocytes. Blood, 113: 5857-5867. https://doi.org/10.1182/ blood-2008-11-188888

Bustin, S.A., 2000. Absolute quantification of mRNA using real-time reverse transcription polymerase chain reaction assays. J. mol. Endocrinol., 25: 169193. https://doi.org/10.1677/jme.0.0250169

Cellot, S. and Sauvageau, G., 2007. ZFX: At the crossroads of survival and self-renewal. Cell, 129: 239-241. https://doi.org/10.1016/j.cell.2007.04.002

Chandrasekharan, S., Kumar, S., Valley, C.M. and Rai, A., 2009. Proprietary science, open science and the role of patent disclosure: The case of zinc-finger proteins. Nat. Biotechnol., 27: 140-144. https://doi. org/10.1038/nbt0209-140

Davies, J.A., 2002. Morphogenesis of the metanephric kidney. Scient. World J., 2: 1937-1950. https://doi. org/10.1100/tsw.2002.854

Fang, Q., Fu, W.H., Yang, J., Li, Y., Zhou, Z.S., Chen, Z.W. and Pan, J.H., 2014. Knockdown of ZFX suppresses renal carcinoma cell growth and induces apoptosis. Cancer Genet., 207: 461-466. https:// doi.org/10.1016/j.cancergen.2014.08.007

Galan-Caridad, J.M., Harel, S., Arenzana, T.L., Hou, Z.E., Doetsch, F.K., Mirny, L.A. and Reizis, B., 2007. ZFX controls the self-renewal of embryonic and hematopoietic stem cells. Cell, 129: 345-357. https://doi.org/10.1016/j.cell.2007.03.014

Giulietti, A., Overbergh, L., Valckx, D., Decallonne, B., Bouillon, R. and Mathieu, C., 2001. An overview of real-time quantitative PCR: Applications to quantify cytokine gene expression. Methods, 25: 386-401. https://doi.org/10.1006/meth.2001.1261

Jiang, H., Zhang, L., Liu, J., Chen, Z., Na, R., Ding, G., Zhang, H. and Ding, Q., 2012. Knockdown of zinc finger protein $\mathrm{X}$-linked inhibits prostate cancer cell proliferation and induces apoptosis by activating caspase-3 and caspase-9. Cancer Gene Ther., 19: 684-689. https://doi.org/10.1038/cgt.2012.53

Kallio, J.P., Hirvikoski, P., Helin, H., Luukkaala, T., Tammela, T.L., Kellokumpu-Lehtinen, P. and Martikainen, P.M., 2004. Renal cell carcinoma MIB-1, BAX and Bcl-2 expression and prognosis. $J$. Urol., 172: 2158-2161. https://doi.org/10.1097/01. ju.0000144334.97639.bf

Li, C.Y., Li, H.J., Zhang, T., Li, J.M., Ma, F.L., Li, M., Sui, Z.F. and Chang, J.W., 2015. ZFX is a Strong Predictor of Poor Prognosis in Renal Cell
Carcinoma. Med. Sci. Monit., 21: 3380-3385. https://doi.org/10.12659/MSM.894708

Li, X.M., Zang, D.Y. and Guo, M., 2006. Cell proliferation and apoptosis in mouse kidney during postnatal development. Chinese J. Anat., 29: 446449.

Lipschutz, J.H., 1998. Molecular development of the kidney: A review of the results of gene disruption studies. Am. J. Kidney Dis., 31: 383-397. https:// doi.org/10.1053/ajkd.1998.v31.pm9506676

Livak, K.J. and Schmittgen, T.D., 2001. Analysis of relative gene expression data using real-time quantitative PCR and the 2(-Delta Delta C(T)) method. Methods, 25: 402-408. https://doi. org/10.1006/meth.2001.1262

Luoh, S.W., Bain, P.A., Polakiewiez, R.D., Goodheart, M.L., Gardner, H., Jaenisch, R. and Page, D.C., 1997. ZFX mutation results in small animal size and reduced germ cell number in male and female mice. Development, 124: 2275-228.

Nikpour, P., Emadi-Baygi, M., Mohammad-Hashem, F., Maracy, M.R. and Haghjooy-Javanmard, S., 2012. Differential expression of ZFX gene in gastric cancer. J. Biosci., 37: 85-90. https://doi. org/10.1007/s12038-011-9174-2

Nyengaard, J.R., 1993. The quantitative development of glomerular capillaries in rats with special reference to unbiased stereological estimates of their number and sizes. Microvasc. Res., 45: 243-261. https://doi. org/10.1006/mvre.1993.1022

Ouyang, Z., Zhou, Q. and Wong, W.H., 2009. ChIPSeq of transcription factors predicts absolute and differential gene expression in embryonic stem cells. Proc. natl. Acad. Sci. USA, 106: 2152121526. https://doi.org/10.1073/pnas.0904863106

Rodríguez, A., Rodríguez, M., Córdoba, J.J. and Andrade, M.J., 2015. Design of primers and probes for quantitative real-time PCR methods. Methods Mol. Biol., 1275: 31-56. https://doi. org/10.1007/978-1-4939-2365-6_3

Saikumar, P., Dong, Z., Weinberg, J.M. and Venkatachalam, M.A., 1998. Mechanisms of cell death in hypoxia/reoxygenation injury. Oncogene, 17: 3341-3347. https://doi.org/10.1038/ sj.onc. 1202579

Schneider-Gadicke, A., Beer-Romero, P., Brown, L.G., Mardon, G., Luoh, S.W. and Page, D.C., 1989. Putative transcription activator with alternative isoforms encoded by human ZFX gene. Nature, 342: 708-711. https://doi.org/10.1038/342708a0

Schnidar, H., Eberl, M., Klingler, S., Mangelberger, D., Kasper, M., Hauser-Kronberger, C., Regl, 
G., Kroismayr, R., Moriggl, R., Sibilia, M. and Aberger, F., 2009. Epidermal growth factor receptor signaling synergizes with Hedgehog/GLI in oncogenic transformation via activation of the MEK/ERK/JUN pathway. Cancer Res., 69: 12841292. https://doi.org/10.1158/0008-5472.CAN-082331

Tang, X.S., Xu, H., Shen, Q., Sun, L., Miao, Q.F., Zhou, L.J., Cao, Q., Liu H.M., Chen, J., Rao, J., Zhai, Y.H. and Fang, X.Y., 2014. The spectrum of causes for end-stage renal disease in 113 pediatric patients. Med. J., 37: 382-385.

Terzi, F., Burtin, M. and Friedlander, G., 2000. Cellular proliferation and apoptosis in the development and progression of renal diseases: Pharmacological interventions in genetically modified animals. Annls. Pathol., 20: S3-51.

Veis, D.J., Sorenson, C.M., Shutter, J.R. and Korsmeyer, S.J., 1993. Bcl-2-deficient mice demonstrate fulminant lymphoid apoptosis, polycystic kidneys, and hypopigmented hair. Cell, 75: 229-240. https:// doi.org/10.1016/0092-8674(93)80065-M

Yamamoto, K., Tomita, N., Yoshimura, S., Nakagami,
H., Taniyama, Y., Yamasaki, K., Ogihara, T. and Morishita, R., 2004. Hypoxia-induced renal epithelial cell death through caspase-dependent pathway: role of Bcl-2, Bcl-xL and BAX in tubular injury. Int. J. mol. Med., 14: 633-640. https://doi. org/10.3892/ijmm.14.4.633

Yang, J., Lin, X., Kim, C.N., Ibrado, A.M., Cai, J., Peng, T.I., Jones, D.P. and Wang, X., 1997. Prevention of apoptosis by Bc-12: Release of cytochrome $\mathrm{C}$ from mitochondria blocked. Science, 275: 1129-1131. https://doi.org/10.1126/science.275.5303.1129

Zang, D.Y., Li, X.M. and Guo, M., 2007. Relationship between the expressions of Bcl-2 and BAX and cell apoptosis in renal medullary of mice during postnatal development. J. Clin. Rehab. Tissue Engineer. Res., 11: 1473-1475.

Zhou, Y., Su, Z., Huang, Y., Chen, S., Wu, T., Chen, G., Xie, X., Li, B. and Du, Z., 2011. The ZFX gene is expressed in human gliomas and is important in the proliferation and apoptosis of the human malignant glioma cell line U251. J. exp. clin. Cancer Res., 30: 114. https://doi.org/10.1186/1756-9966-30-114 